María Cecilia Graña

\title{
Barloventear y singlar: la poética compleja de Cristina Peri Rossi
}

e il naufragar m’è dolce in questo mare.

G. Leopardi, L'infinito

\section{Arte poética: «Barloventear» y «singlar»}

La autora uruguaya Cristina Peri Rossi, exiliada en España en 1972 donde todavía reside (tomó la nacionalidad española en 1975) en una compleja condición «transatlántica», ${ }^{1}$ da una notable relevancia - desde un punto de vista teórico pero también en su poesía - al tema de la ars poetica - sintagma que aparece por primera vez en las Instituciones oratorias de Quintiliano y cuya praxis tiene su antecedente más conocido en la Epístola a los Pisones de Horacio: treinta hexámetros que aconsejan la armonía y la proporción textual, la verosimilitud y la dialéctica entre lo útil y lo deleitable-. A partir de entonces, mucha agua ha corrido bajo los puentes, y al llegar al siglo XIX el hecho de que Hegel decretase que dentro de la nueva sociedad burguesa el arte dejó de ser la más alta necesidad del espíritu ${ }^{2}$ dio un giro de tuerca a la mirada sobre las manifestaciones artísticas centradas en una visión analógica del mundo que crea la ilusión de reinstalar la unión perdida. Desde ese momento se acentúa una perspectiva que colinda o está en yuxtaposición con el discurso crítico y que, por esto mismo, se acerca más a

1 Condición que comprende a aquellos escritores que por razones diversas han acabado por vivir y producir en un continente «otro» respecto del propio (Cfr. Claudio Guillén, «El sol de los desterrados: Literatura y exilio». In: Múltiples moradas: Ensayo de literatura comparada, p. 29-97. Barcelona: Tusquets 1998, y Milena Rodríguez, «Poetas transatlánticas: hispanoamericanas en la España de hoy. Cristina Peri Rossi, Ana Becciu, Isel Rivero». In: Anales de literatura hispanoamericana 38 (2009), p. 111-133) y cuya obra anima a la crítica a estudiar «lo que sabemos unos de otros» y «lo que no sabemos uno del otro» (Julio Ortega, «Post-teoría y estudios transatlánticos». In: Iberoamericana 9 (2003), p. 109-117).

2 Georg F. Hegel: Estética, vol. 1. Torino: Einaudi 1997, p. 15-16.

María Cecilia Graña, Università degli Studi di Verona

ว Open Access. (C) 2021 María Cecilia Graña, published by De Gruyter. (๕) BY-NC-ND This work is licensed under the Creative Commons Attribution-NonCommercial-NoDerivatives 4.0 International License. 
lo que Paz define como «ironía»: ${ }^{3}$ esa suerte de «función reflexiva, responsable última de la tendencia a proponerse como meta-poesía que todo poema revela» ${ }^{4}$

\subsection{Poética explícita}

La reflexión metapoética es algo que explícitamente Cristina Peri Rossi reitera y manifiesta en entrevistas y ensayos ${ }^{5}$ y esta reflexión se basa, fundamentalmente, en su rechazo por cualquier fijeza («el afán de la crítica es encasillar, el afán del creador es romper los géneros, romper los esquemas y desencasillarse $»^{6}$ ). Por esto mismo, la autora no quiere ser identificada con un único estilo porque este, entendido como una perspectiva de visión ${ }^{7}$ «es reduccionista» y solo permite «abordar ciertos aspectos». ${ }^{8}$ En efecto, como respuesta a la primera catalogación - «politizada» y luego «diaspórica»- que se hizo de su obra, su quinta publicación pero primer libro de poesías, Evohé, de 1971, se ubica en una vertiente que dará lugar a una nueva casilla en esa Wunderkammer que es la summa perirossiana. Desde el título (onomatopeya del grito de las bacantes) al subtítulo, Poemas eróticos, se delinea la intención de aparecer en la escena literaria con una tipología que parece anular los límites entre lo privado y lo público. El libro constituyó un escándalo - como Peri Rossi declara en el «Prólogo» de su Poesía Reunid $a^{9}$-; prohibido en Uruguay y reeditado tan sólo en traducción inglesa casi veinticinco años después, este poemario empieza a deconstruir con ironía la imagen femenina que la cultura patriarcal había creado, un proceso que la autora habrá de proseguir a lo largo del tiempo. ${ }^{10}$

3 Octavio Paz: Los hijos del limo. Barcelona: Seix Barral 1990, p. 110.

4 José María Pozuelo Yvancos: «Pragmática, poesía y metapoesía en «El Poeta〉 de Vicente Aleixandre». In: Fernando Cobo (ed.): Teorías sobre la lírica. Madrid: Arco Libros 1999, p. 181.

5 Cristina Peri Rossi: «Escribir como transgresión». In: Lectora: revista de dones y textualitat 1 (1995).

6 Nicola Gilmour: «Una entrevista con Cristina Peri Rossi». In: Journal of Iberian and Latin American Studies 6-1 (2000), p. 123.

7 «Tener un estilo es tener un solo ángulo para mirar la realidad», en cambio, «variar un estilo implica variar la relación con el mundo» (Gustavo San Román: «Entrevista a Cristina Peri Rossi». In: Revista Iberoamericana LVIII, 160-161 (1992), p. 1043).

8 Nicola Gilmour: «Una entrevista», p. 126.

9 Cristina Peri Rossi: Poesía Reunida. Barcelona: Lumen 2005, p. 12.

$10 \mathrm{Al}$ respecto, vale la pena considerar las reflexiones de A. Salomone sobre los conceptos de analogía e ironía dentro del discurso femenino, pues la crítica argentino-chilena nota cómo «las figuraciones críticas y/o irónicas en sus más variadas formas (. . .) suelen ser indisociables en el discurso de mujeres cuando estas adoptan una posición crítica como sujetos frente al mandato sociocultural del silencio y la subordinación» (Alicia Salomone: «Analogía, ironía y escritura 
Hay en su obra un constante anhelo por transgredir todo orden canónico, autoritario o establecido y, especialmente, hacerlo como mujer; ${ }^{11}$ su afán de «barloventear», de dirigir contra el viento esa nave que es su obra poética, se traduce en una amplitud de intereses que van, inicial y gradualmente, pasando de poesías de carácter político (como el poema XV de Estado de Exilio) a otras como en el poema XI, que esbozan la función de la literatura alejándola de lo útil para acercarla a lo deleitable, incluso en situaciones extremas: «Pero cuando una palabra escrita / en el margen en la página en la pared / sirve para aliviar el dolor de un torturado, / la literatura tiene sentido». ${ }^{12}$

Este intento constante de apertura y transgresión se concreta en modos diversos y con él se confirma la clásica definición de poesía lírica entendida como «antidiscurso por su vocación y capacidad para la transgresión de cualquier esquema genérico, descriptivo, narrativo, argumentativo, temporal, etc.», ${ }^{13}$ algo que en la praxis retórica de Peri Rossi se concreta en la dimensión metafórica y metaléptica. Con la reiteración, tematización y configuración de imágenes, campos semánticos y sujetos poéticos que invaden o se dejan invadir por otros, la autora uruguaya perfila con vigor el fundamento de su obra, es decir, la idea de límite o de frontera que aparece unida estrechamente a otro cimiento de su poética, el deseo, como ella misma lo declara en el «Prólogo» a su Poesía reunida: "podría decir que el tema más frecuente [de mi obra] es el deseo, como pulsión de vida o de muerte». ${ }^{14}$ Pulsión o energía vital que impulsa a buscar lo que no está, que implica tratar de compensar con la escritura una ausencia o expresar con el lenguaje lo que, en última instancia y desgraciadamente, es inefable. Así pues, la frontera, espacio paradigmático en Peri Rossi, es también el lugar del deseo porque acarrea consigo el concepto de «término», cuya raíz «ter〉 significa 〈atravesar», 〈alcanzar una meta〉 ubicada siempre «más allá»» (recuerda Pavel Florensky ${ }^{15}$ ). Es que, en realidad, tanto la frontera como el deseo implican movimiento y tránsito: «Y nunca el deseo arrojó el ancla / de modo que me vi obligada / a navegar» («El deseo IV»). ${ }^{16}$

femenina: Repensando a Octavio Paz desde la teoría crítica feminista». In: Taller de Letras 38 (2006), p. 94).

11 Cristina Peri Rossi: «Escribir», p. 3-6.

12 Cristina Peri Rossi: Poesía, p. 300.

13 Arturo Casas: «Pragmática y poesía». In: Darío Villanueva (compil.): Avances en Teoría de la Literatura (Estética de la Recepción, Pragmática, Teoría Empírica y Teoría de los Polisistemas). Santiago de Compostela: Universidad de Santiago de Compostela 2012 [1994], p. 436.

14 Cristina Peri Rossi: Poesía, p. 21.

15 Pavel Florensky en Jorge Lozano: «Sin límites: Fronteras y confines en la semiótica de la cultura». In: Fronteras. De Signis 13 (2009), p. 183.

16 Cristina Peri Rossi: Poesía, p. 823. 
En la frontera también aparecen situados algunos de los personajes de la poesía perirossiana, como la figura amada de la primera parte de Lingüística General que «[S]e pasea altiva / por los bordes de este mundo / ya con reminiscencias de los otros» («Ella»). ${ }^{17}$

Pero, además, el deseo en Peri Rossi es también el impulso, que bien se puede definir romántico, de unir lo fragmentado para recuperar el Uno inicial ya perdido y que solo en la infancia fue posible percibir (como en «Infancia» o en «Lejano paraíso», en La noche y su artificio); anhelo que es consecuencia de la condición diaspórica de la escritora, en la que «la alteridad se sueña unidad, y la diferencia se proyecta ilusoriamente como identidad». ${ }^{18}$

La idea de transgredir un límite se manifiesta, asimismo, en el intento de los sujetos poéticos de retrotraerse al pasado para fijarlo en una poesía que reflexiona sobre sí cuando dice: «Sólo lo inmediato es verdadero / Salvo para la poesía» («Contra la filosofía»). ${ }^{19}$ De hecho, más de una vez el sujeto poético se empeña en recuperar el pasado para memoria futura; frente a los edificios desaparecidos en «El auge de la edificación» se dice: «. . . escribo este poema: / para que existan en la página blanca / en los pliegues de las letras. / [. . . Contra el viento devastador que destruye / la memoria» («El auge de la edificación»). ${ }^{20}$ En otros casos, inversamente, el yo se configura como una Casandra a cuyo llamado nadie acude o al que nadie le cree («Fatalidad»; «Lo fatal Rubén Darío»); ${ }^{21}$ de esta forma el tiempo se desliza hacia el futuro anticipándolo, tal como sucedió con Indicios pánicos - colección de cuentos, aforismas y poemas de 1970-, en el que se preanunciaba lo que había de ser la dictadura en Uruguay y como volvió a suceder con Europa después de la lluvia de 1987 que, a posteriori, fue leído como un anuncio de la caída del muro de Berlín.

Estos deslizamientos temporales se anudan textualmente con el concepto de arte poética, como lo demuestran «Poética», de Otra vez Eros y el poema IV de Lingüística General:

17 Ibid., p. 404.

18 Octavio Paz: Los hijos, p. 80.

19 Cristina Peri Rossi: Poesía, p. 609.

20 Ibid., p. 604.

21 Algo que Peri Rossi confirma en un ensayo: «Por eso el mito que más me inspira, me conmueve y seduce es el de Casandra destinada a adivinar el futuro sin que nadie le crea [. . . ]. Los escritores somos muchas veces Casandras extraviadas en el infierno de la existencia sin tener quien nos escuche» (Cristina Peri Rossi: «Detente, instante eres tan bello». In: Jesús Gómez-de-Tejada (coord.): Cristina Peri Rossi: Erotismo, transgresión y exilio. Las voces de Cristina Peri Rossi, coordin. de Jesús Gómez de Tejada. Sevilla: EUS 2017, p. 28). 


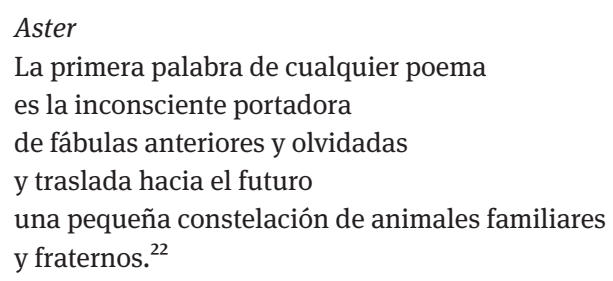

La poesía nos dice de otra forma que «la palabra poética adviene de tal modo que su advenimiento se escapa ya siempre hacia un futuro y hacia el pasado y el lugar de la poesía es siempre el lugar de la memoria y la repetición». ${ }^{23}$

La escritora, consciente o inconscientemente, abre las compuertas de todas las fronteras buscando también "espacios teóricos transitables y permeables» ${ }^{24}$ para abocar en una estrategia escritural basada en la transdisciplinariedad; basta leer, por ejemplo, las écfrasis en Europa después de la lluvia y Las musas inquietantes, o bien los intereses por algunos aspectos científicos en La noche y su artificio («ADN», «Leyes físicas»), psicoanalíticos o sociológicos del mundo actual (i.e., «Grandes almacenes», ${ }^{25}$ «Nocturno urbano» ${ }^{26}$ ).

\subsection{Poética implícita}

En «Verena traduce un libro antiguo de viajes», Peri Rossi introduce un sintagma: «singla el viento» ${ }^{27}$ que, dentro de las metáforas marineras predilectas de la autora, apunta a la imagen de una nave que toma un rumbo determinado. En este caso aquel en el que la idea de poesía se transforma cuando se produce la convergencia entre creación y teoría; es decir, cuando el yo autoral, desdoblándose en el sujeto poético, explica algunas cosas propias, a sabiendas de que las está volviendo públicas bajo la forma de la poesía, dando lugar a un detrimento gradual de la importancia del referente para acrecentar el área de lo autorreferencial y del lenguaje. Este tipo de poesías, generalmente definidas como «poéticas de autor», en nuestra lengua como en otras se prestaron para ser recopiladas

22 Cristina Peri Rossi: Poesía, p. 372.

23 Giorgio Agamben: El lenguaje y la muerte: Un seminario sobre el lugar de la negatividad. Valencia: Pre-Textos 2008, p. 124.

24 Raúl Magallón Rosa: «Vagabundos de identidad». In: Fronteras. De Signis 13 (2009), p. 16.

25 Cristina Peri Rossi: Poesía.

26 Cristina Peri Rossi: Habitación de hotel. Barcelona: Plaza y Janés 2007.

27 Cristina Peri Rossi: Poesía, p. 487. 
aunque, las antologías parecen demostrarlo, han sido más frecuentadas por los hombres que por las mujeres. ${ }^{28}$

Antes de adentrarnos en estos textos de la autora uruguaya, hay que recordar que la «metapoesía» es la tipología «que presenta mayor atraso teórico», ${ }^{29}$ posiblemente porque forma parte de un dominio borroso

en el que se incorporaría una serie abierta de manifestaciones textuales, cuando menos convergentes en un punto, el de dar paso explícito o implícito a una declaración o postulación de principios o presupuestos estéticos y/o poéticos que un escritor hace pública en relación con la obra propia bajo condiciones intencionales y discursivas muy abiertas. ${ }^{30}$

En efecto, en la obra de Peri Rossi, a partir de Lingüística general (1979) aparecen siempre con mayor frecuencia textos titulados «Poética» o que sin este título hacen, sin embargo, referencia a ella. La autora uruguaya en sus poesías incorpora implícitamente reflexiones sobre la forma, el deseo, la intención de las mismas, acompañando de este modo sus declaraciones explícitas en ensayos, comentarios e, incluso, en los prólogos de su obra donde, por momentos, parece estar haciendo su propia crítica literaria. Y en esta declaraciones implícitas o explícitas, Peri Rossi coincide con la visión de Jakobson, para quien la «poeticidad», es vagamente descrita «como un componente transformador de todos los otros elementos presentes en el texto poético [. . . ] y comparada por ello con el aceite de cocina»; ${ }^{31}$ poeticidad en la que la palabra es vista como tal y no como un simple substituto del objeto ni como la explosión de una emoción: algo que el primer poema de Lingüística General pone en evidencia.

Si el discurso poético perirossiano aparece caracterizado por una densidad intencional de rasgos lingüísticos que es lo que distingue lo literario de la lengua estándar $^{32}$ sus declaraciones metapoéticas, claramente diferencian la narrativa de la especificidad de la poesía, porque en cada caso el objeto comunicativo es de naturaleza diversa. Para la autora, «narrar es operación mucho más primitiva del cerebro que versificar», mientras que «la poesía prescinde de todos los referentes

28 Arturo Casas: «La función autopoética y el problema de la productividad histórica». In: Romera Castilla y Gutiérrez Carbajo (eds.): Poesía histórica y autobiográfica. Madrid: Visor 2000, p. 211. 29 Laura Scarano: «Escribo que escribo: de la metapoesía a las autopoéticas». In: Tropelías. Revista de Teoría de la LIteratura y Literatura Comparada 2 (2017), p. 135.

30 Arturo Casas: «La función», p. 210.

31 Jackobson cit. en Arturo Casas: «Pragmática», p. 268.

32 Antonio García Berrio: «Lingüística, literaridad/poeticidad (gramática, pragmática, texto)». In: 1616. Anuario de la Sociedad Española de Literatura General y Comparada 2 (1979). 
narrativos, es metáfora de la realidad». ${ }^{33}$ En pocas palabras, para la narrativa el objeto es la experiencia representada; para la poesía es el «descubrimiento compartido». ${ }^{34}$ En efecto, Peri Rossi se acerca a la materia poética con la intención última de sorprender al lector y sorprenderse escribiendo algo portador de un nuevo conocimiento y una nueva forma de escritura. Y esta visión la mantiene constantemente a lo largo de su recorrido literario aunque ese mensaje aparezca como destinado a un lector y no a un futuro escritor, así en su penúltimo volumen de poesías, Habitación de hotel, frente al pedido «Enséñame» de una joven de veintiún años a la escritora de más de sesenta, sujeto poético de «Asombro», esta última oculta

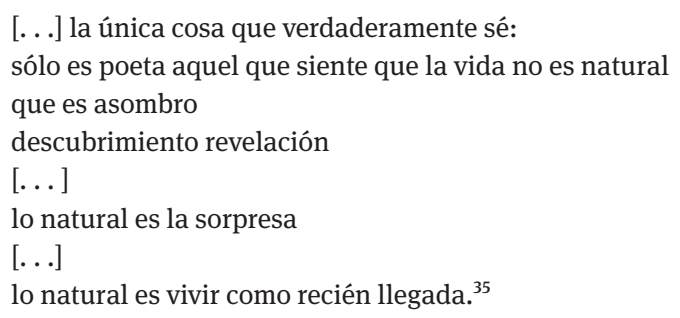

Como ha señalado Fariña Busto, la escritura de Peri Rossi «puede leerse como un tratado del deseo al mismo tiempo que, en íntima correspondencia, como un tratado de teoría poética». ${ }^{36}$ Teniendo en cuenta ambos asuntos, basta observar que la serie de poesías con las que inicia Evohé se encadenan unas con otras («Definiciones», «Lucas IV, «Dedicatoria», «Dedicatoria II» y «Prólogo») y tienen títulos que están reclamando irónicamente la atención del lector hacia aspectos que anticipan y organizan la escritura. Fundamentalmente, el arte poética en este primer volumen consiste en tomar posesión de la lengua y de la mujer borrando las fronteras entre una y otra:

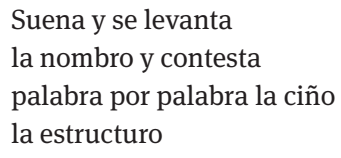

33 Claudia Pérez: «Entrevista a Cristina Peri Rossi». In: Jesús Gómez-de-Tejada (coord.): Cristina Peri Rossi: Erotismo, p. 367.

34 Antonio García Berrio: «Lingüística», p. 168.

35 Cristina Peri Rossi: Habitación, p. 74.

36 María Jesús Fariña Busto: «Donde habita el deseo: Eros y el lenguaje poético». In: Jesús Gómez-de-Tejada (coord.): Cristina Peri Rossi: Erotismo, p. 71. 
como a una frase

y luego que la he hecho verso,

duerme, como una lengua muerta. ${ }^{37}$

Este deslizamiento de uno a otro lado de la barra que separa el significado (el acto sexual) del significante (la palabra) que sirve para representarlo, difumina las diferencias tradicionales entre lo representado y su representación. Es quizás este dinamismo el que hace que el primer volumen poético de Cristina Peri Rossi logre mantener, no obstante el paso de los años, su intensa carga erótica. Por lo tanto, al deslizarse del cuerpo a la palabra y viceversa, dotando a ambos, alternadamente, del mismo valor semántico, revela que a la situación de habla en el poemario no le interesa obtener un «efecto de realidad» ${ }^{38}$ sino, más bien, crear un efecto de extrañamiento - algo considerado frecuente en el discurso perirossiano. ${ }^{39}$

Hay que señalar que en Poesía reunida, de 2005, Evohé presenta algunas variaciones respecto de la primera edición de 1971 publicada por la editorial Girón de Montevideo, como se recuerda en el «Prólogo» de Poesía, donde algunas se aclaran (i.e., una de las dos citas que encabezan el libro, la de Safo, se quita para pasar a un volumen posterior, Otra vez Eros, de 1994); mientras que otras no se explicitan, como el cambio de género del hablante, ahora femenino como el tú («¿Qué es lo que quiere, esa poeta?»); ${ }^{40}$ un cambio relativo porque quedaron algunas marcas masculinas. En consecuencia, si en la primera edición se podía pensar en una actitud polémica subyacente en la que «el poeta, en masculino, es dueño de la palabra» $\mathrm{y}$ «crea la figura femenina por medio de la palabra», ${ }^{41}$ esta actitud en Poesía Reunida desaparece, porque la autora siempre pensó que la identidad es algo que admite la duda o que transita por las contradicciones. Como

37 Cristina Peri Rossi: Poesía, p. 90.

38 Claudia Magliano:»La poesía persigue lo efímero». In: Jesús Gómez-de-Tejada (coord.): Cristina Peri Rossi: Erotismo, p. 356.

39 La afinidad entre la palabra y la mujer es algo que relaciona la obra de Peri Rossi con algunos textos de Neruda y sobre todo con los de Octavio Paz. De hecho, Hugo Verani, uno de los primeros en ocuparse de la obra poética de la uruguaya notó, tempranamente (cfr. Hugo Verani: «Muestras de la poesía uruguaya actual». In: Hispamérica 16 (1977) y «La rebelión del cuerpo y el lenguaje (A propósito de Cristina Peri Rossi)». In: Revista de la Universidad de México 37, 11 (1982), la afinidad en este punto entre el mexicano y Peri Rossi. Sin embargo, si Paz apunta a una suerte de panteísmo en el que lo erótico es una manifestación del mismo, Peri Rossi disuelve o intensifica el eros - sobre todo en sus primeros libros de poemas- entre las vocales y consonantes de la lengua.

40 Cristina Peri Rossi: Poesía, p. 36.

41 María Jesús Fariña Busto: «Donde habita», p. 72. 
ella misma dice: «[S]e ha querido hacer del sexo y del género lo mismo y son dos cosas distintas. Uno puede tener un sexo y jugar a tener el género que quiera». ${ }^{42}$

Así pues, en Evohé la poesía es una suerte de flujo sexual que se inscribeescribe en los cuerpos acercándose a ellos y distanciándose de los mismos, con ironía: «Una vez que la hube amado, / ella quedó henchida de palabras. / Una vez que la hube pronunciado, / quedó preñada de sonidos». ${ }^{43}$

En el volumen, cuerpo y palabra se vuelven análogos en cuanto la letra puede inscribirse en el soma y viceversa, dando lugar a un mestizaje de lo textual con lo sexual («Las mujeres son palabras de una lengua antigua / y olvidada. / Las palabras, son mujeres disolutas.»; "Lingüîstica» ${ }^{44}$ ) e, indirectamente, a una reflexión metaliteraria sobre la palabra y sobre el deseo. Con esta praxis en la que conjuga cuerpo y palabra abatiendo límites y fronteras, la autora uruguaya confirma la dirección inicial de su poética; algo que se sigue viendo en un volumen posterior, Diáspora (1976) - donde del argumento que da el título al libro, relacionado con una situación política y existencial («de un país que tú no conocías y era mi país / el país abandonado en diáspora / el país ocupado por el ejército nacional»; «Diáspora» ${ }^{45}$ ), hay un deslizamiento hacia temas eróticos (i.e. «La bacante» en sus cuatro versiones»), homoeróticos o «que subvierten la tradición de género» («Prólogo») ${ }^{46}$-, porque en él las palabras siguen manteniendo una preeminencia concreta, lúdica y lúbrica (como en «Cacería para un solo enamorado» ${ }^{47}$ ) o en el poema IX de «Alejandra entre las lilas»: «Después de haberte leído entera / supe que habíamos hecho el amor / muchas veces - qué conflagración». ${ }^{48}$ En Diáspora se observa, además, que la presencia del tú - objeto amoroso que a veces toma la palabra («Penétrame»)—, se vuelve indispensable para hacer poesía, como en «Cautiverio»:

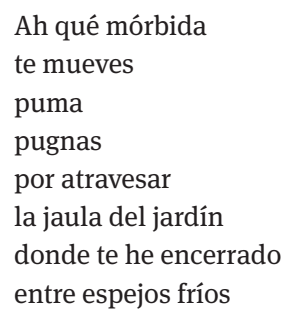

42 Aína Pérez Fondevila: «Del deseo y sus accesos: una entrevista a Cristina Peri Rossi». In: Lectora 11 (2005), p. 186.

43 Cristina Peri Rossi: Poesía, p. 64.

44 Ibid., p. 56.

45 Ibid., p. 231.

46 Ibid., p. 15.

47 Ibid., p. 264-267.

48 Ibid., p. 276. 
para que no te vayas

para hacer poesía. ${ }^{49}$

Un matiz diverso de este aspecto aparece en un poema de Otra vez Eros, «Distancia justa», ${ }^{50}$ donde se reflexiona metapoéticamente sobre cuál es la distancia necesaria para transformar el amor en escritura: «Si te acercas demasiado me excito / me asusto / me obnubilo digo tonterías / me echo a temblar. / Pero si estás lejos / sufro entristezco / me desvelo / y escribo poemas». ${ }^{51}$

Si generalmente en la literatura llamada «erótica», «obscena» o «pornográfica» la comunicación es bastante elemental «porque el referente del que arranca el proceso metafórico será sencillamente una parte del cuerpo, una función física, un acto sexual», ${ }^{52}$ en Peri Rossi, la comunicación de lo erótico no incluye sólo «una imagen o término segundo, vehículo visible de la metáfora [. . .] sino un sentido tercero, una orientación que sustituye el referente y también, sobre todo, lo interpreta y lo piensa $»^{53}$ porque quiere connotar la palabra con el cuerpo y viceversa, de modo tal que el mundo representado pierde su contacto con la realidad para transformarse en una cosa lúdica y preminentemente perirossiana.$^{54}$ Aquí es evidente que el lenguaje se vuelve objeto destacado en la obra de la montevideana porque «la transgresión primera», como indicó Claudio Guillén a propósito de la literatura obscena, «es la expresión. [.. .] la última y la más profunda -hasta llegar, o mejor dicho, hasta «tender a la comunicación de lo indecible». ${ }^{55}$

De esta forma lo indecible de lo erótico se asoma al cargar de eroticidad las palabras y, si en la usual literatura erótica una dosis de agresividad (sexual) se manifiesta a veces en la reiteración de un vocablo obsceno, en Peri Rossi la repetición intensificadora, en los ejemplos arriba mencionados, se apoya en el vocablo «palabra» o en el campo semántico relacionado («verso», »frase») para terminar connotando una suerte de violencia en el acoplamiento:

Cuando damos el combate por finalizado, tiene el cuerpo lleno de palabras

49 Ibid., p. 204.

50 Ibid., p. 603.

51 No es casual que en el «Prólogo» a su Poesía reunida la autora recuerde estas palabras de Bécquer a un amigo: «No escribo cuando estoy emocionado [. . . ] sino cuando recuerdo la emoción» (Cristina Peri Rossi: Poesía, p. 9).

52 Claudio Guillén: «La expresión total: literatura y obscenidad». In: Múltiples moradas. Ensayo de literatura comparada. Barcelona: Tusquets 1998, p. 247.

53 Ibid., p. 247.

54 Cfr. Cristina Peri Rossi: Fantasías eróticas. Barcelona: Ediciones Temas de Hoy 1991.

55 Claudio Guillén: «La expresión», p. 234. 
que sangran por el cuarto

y así, desnuda y herida,

con el cuerpo lleno de señales

le tomo una fotografía. ${ }^{56}$

Se ha dicho que «la historicidad condiciona la transgresión, al mismo tiempo que la solicita y la frena»; ${ }^{57}$ en el caso de Evohé, libro nacido como reacción frente a un contexto pequeño burgués en el que la mujer no parecía tener voz ni deseo, al no hablar estrictamente de la relación sexual salvo representarla como, valga la expresión, «un juego de palabras», en una condición en la que hacer y decir son equivalentes, rechaza cualquier simplificación, cualquier reducción monosémica para mantener su potencia y libertad, a pesar del paso del tiempo.

De esta forma, la lírica perirossiana se conecta en forma original con las direcciones poéticas que surgen luego del Romanticismo, en cuanto resulta un «lenguaje emergente con visible separación de las construcciones referenciales».58 Y precisamente, este inicio poético con un libro de carácter erótico, pero con las peculiaridades que hemos subrayado, indica con particular intensidad el concepto de distancia que Peri Rossi concibe entre la actividad del poetizar y la realidad, concepto que, por cierto, constituye el principal rasgo pragmático de cualquier hablante poético ya que, gracias a esa distancia, «el valor de los deícticos y sus efectos origina un proceso de generalización según el cual el yo-tú del poema se ubica en un circuito propio, extensible a cualquier lector» ${ }^{59}$ y no sólo, ya que pone en evidencia también el particular estatuto de la enunciación en el discurso poético porque «la instancia del discurso a la que el shifter nos refiere, es el tener-lugar mismo del lenguaje en general»: ${ }^{60}$

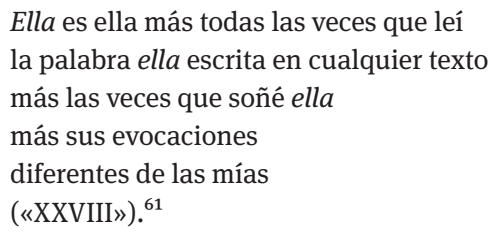

56 Cristina Peri Rossi: Poesía, p. 42.

57 Claudio Guillén: «La expresión», p. 252.

58 Carolina Cayuela González: «Metapoesía y pragmática en «El Poeta〉 de Vicente Aleixandre». In: Espéculo. Revista de Estudios literarios 34 (2006-2007), s. p. https://webs.ucm.es/info/especulo/numero34/metaalei.html [Consultado el 12 de octubre 2020].

59 Carolina Cayuela González: «Metapoesía».

60 Giorgio Agamben: El lenguaje, p. 124.

61 Cristina Peri Rossi: Poesía, p. 401. 
Por cierto que en Peri Rossi este concepto de distancia varía con el tiempo. Por ejemplo, en Otra vez Eros (1976) se ve en la mayor reflexión sobre la frecuentada relación entre el cuerpo de la mujer y el mundo natural (i.e. «Filosofía»); al volver más explícito el tema homoerótico («Estado de celo II»; «Encomienda») y en la mayor implicación del yo autoral en relación con la condición femenina y las cuestiones de género («Genealogía», «Condición de mujer»). Sin embargo, no se olvida que esas cuestiones se manifiestan con palabras y estas de por sí constituyen un simulacro que reabre el trecho que las distancia de la realidad. Así, en «Poética»:

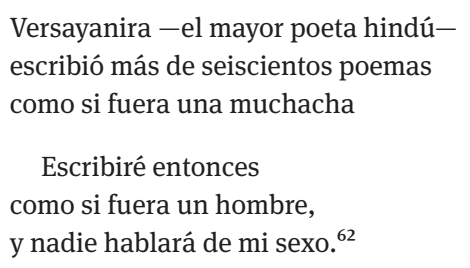

Lingüística general (1979), según la autora, «es un guiño a todas las teorías sobre la poesía, un guiño a los libros que se llaman Lingüística General». ${ }^{63}$ De las tres secciones que la configuran, la primera concentra la mayor parte de las poesías «autorreflexivas». Muchas de ellas se detienen sobre el intervalo que existe entre la imago mental y la realidad porque «[E]n la nostálgica distancia que va / del sueño a lo real / se instala la alquimia del poema y del amor» («XXI»). ${ }^{64}$ Pero otras se detienen sobre el hecho de que al poeta le importa menos el referente que las palabras que ya lo han nombrado. («Ningún poema sobre la puesta de sol / llamada también ocaso / o atardecer / trata en sí de la puesta de sol / sino de las refracciones idiomáticas / de un ocaso que en nuestra lengua tiene / reminiscencias de azar, / que por otra parte recuerda al azor, / sin el cual, difícilmente, existe el atardecer»; «II»). ${ }^{65}$

Este punto de arranque en la teorización del acto poético va sufriendo una gradual evolución al introducirse la temática amorosa en la que es siempre más frecuente la presencia de un fantasmal «arce azul» que aparece por primera vez el día en que las amantes se conocen y cuyo silbo parece provenir de la figura amada.

Y no sé si de lejos me reclama un arce azul

62 Ibid., p. 637.

63 Cristina Peri Rossi: «Lectura comentada». In: R. Mérida Jiménez (ed.): Diàlegs, gais, lesbians, queers. Lleida: Universitat de Lleida 2007, p. 28.

64 Cristina Peri Rossi: Poesía, p. 392.

65 Ibid., p. 370. 


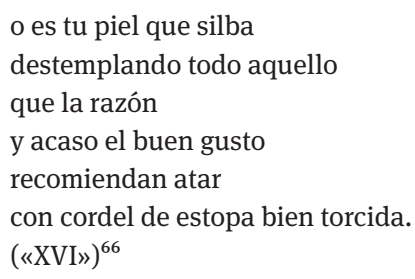

Ese silbo se vuelve, al mismo tiempo, metáfora del pneuma creativo («Silbas en mi memoria / que es imaginación»; «XV») ${ }^{67}$ haciendo que eros, amor y poesía se vuelvan equivalentes, pues, como señala Octavio Paz:

[A]spiramos y respiramos el mundo, con el mundo, en un acto que es ejercicio respiratorio, ritmo, imagen y sentido en unidad inseparable. Respirar es un acto poético porque es un acto de comunión. En ella, y no en la fisiología, reside lo que Etiemble llama «el placer poético». ${ }^{68}$

De esta forma se ve cómo Peri Rossi rescata aquí la vivencia de los trovadores provenzales; las palabras para ella son «estrategias del deseo»; ${ }^{69}$ quiere vivir el amor rememorándolo no tanto como acontecimiento psicológico o biográfico, sino más bien como una «tentativa de vivir el tópos mismo, el acontecimiento de lenguaje como fundamental experiencia amorosa y poética» ${ }^{70}$ porque «[E]l 〈aparato de la mente, del que nace la palabra, va precedido, pues, del deseo, que no tiene paz hasta que el objeto del deseo ha sido encontrado». ${ }^{71}$

La autora, a través de los sujetos poéticos de Lingüística General, ahonda la reflexión sobre las relaciones entre la realidad y su representación; la poesía logra expresar un tipo de verdad que va más allá de la que todos creemos que sea («La poesía verdadera excluye la sinceridad / en el sentido banal / pero jamás admite la hipocresía», «XXIII») $)^{72} \mathrm{y}$, con «nostalgia de infinito» («XXII»), ${ }^{73}$ anhela revelar algo que adquiere, así, una valencia estética y metafísica ( «Soy ambigua - dice la poesía- / como toda revelación»; «XXIV $\left.»^{74}\right) .{ }^{75}$ Peri Rossi retoma a Borges no solo

66 Ibid., p. 387.

67 Ibid., p. 386.

68 Octavio Paz: El arco, p. 207-208.

69 Cristina Peri Rossi: Poesía, p. 771.

70 Giorgio Agamben: El lenguaje, p. 111.

71 Ibid., p. 110.

72 Cristina Peri Rossi: Poesía, p. 394.

73 Ibid., p. 393.

74 Ibid., p. 395.

75 Una visión que recuerda la de J. L. Borges, quien decía: «La música, los estados de felicidad, la mitología, las caras trabajadas por el tiempo, ciertos crepúsculos y ciertos lugares, quieren 
en la importancia que le da a la revelación sino, asimismo, cuando toca el tema de la tradición poética, porque si para la uruguaya el poeta «se parece al profeta» («VIII»), ${ }^{76}$ aunque escribe, sobre todo, «hacia el pasado»y «sólo descubre una tradición» («Poética»), ${ }^{77}$ el argentino se refería a la literatura como la diversa entonación de una cuantas - pero no infinitas- metáforas.

Si en algunas poesías de Peri Rossi el eludir la verdad de las cosas con nombres inventados sirve para obtener de la amada una respuesta, esta última emerge de un ámbito originario, «. . .desde el fondo de la lengua, / allí donde el nombre de las cosas / es todavía víscera profunda / antes que acuerdo y convención» («XXVII»). ${ }^{78}$ Por lo tanto, recuperar esa entraña anterior al lenguaje es la difícil tarea del poeta y, en particular, del poeta «desentrañado», ${ }^{79}$ exiliado. Como vemos, en la obra de Peri Rossi, a pesar del gran peso de la tradición literaria, una importancia inusitada adquiere todo aquello que emerge de una experiencia primigenia con una carga primordial que lo artistizado puede reproducir tan sólo como simulacro o simulación.

Foucault ha señalado que para los lingüistas, el signo no posee sentido si no es a través del juego y la soberanía de todos los otros signos, habiendo perdido la relación inmediata con eso que él significa. Sin embargo recuerda que, en ámbito religioso, se encuentran con frecuencia signos de otro tipo (supongamos el árbol de la cruz) que hablan a través de una profunda pertenencia al origen y son proféticos e irónicos ${ }^{80}$ porque no ofrecen un sentido, sino una momentánea iluminación. La visión de Peri Rossi coincide con la de Foucault («El poeta no escribe sobre las cosas, / sino sobre el nombre de las cosas», «I»; ${ }^{81}$ «. . .el poeta no habla de los seres, / sino de símbolos», «Poética» ${ }^{82}$ ) y se propone encontrar signos arraigados a un manantial originario.

decirnos algo, o algo dijeron que no hubiéramos debido perder, o están por decir algo; esta inminencia de una revelación, que no se produce, es, quizá, el hecho estético». (Borges, La muralla, y los libros. In: Obra completa. 1923-1972. Buenos Aires: Emecé 1974, 635).

76 Cristina Peri Rossi: Poesía, p. 376.

77 Ibid., p. 399.

78 Ibid., p. 400.

79 Según Pérez Firmat, el antónimo de «extraño» es «entraña» y la «oposición entre extraño y entraña halla confirmación nada menos que en la etimología de sexilio» que algunos diccionarios derivan de ex-ilia, sacar las ilia o las entrañas» (Gustavo Pérez Firmat: Cincuenta lecciones de exilio y desexilio. Miami: Universal 2000, p. 41).

80 Michel Foucault: «La prose d’Actéon». In: Dits et écrits 1954-1988, tomo I, 1954-1969, ed. D. Defert y F. Ewald. Paris: Gallimard 1964, p. 330.

81 Cristina Peri Rossi: Poesía, p. 369.

82 Ibid., p. 555. 
Para el yo poético perirossiano escribir no consiste en representar la cosa sino la imagen mental de la cosa (quizás por eso se define como «un espejo que al reproducir / evoca», «Sistema poético»; ${ }^{83}$ ) y aunque afirme que «mi melancolía y yo hemos decidido / vivir en el pasado» («El tiempo»), ${ }^{84}$ sabe que la imagen mental ha distorsionado lo que ha sido visto porque la memoria de por sí traduce, y como tal, traiciona. El yo en, por ejemplo, Europa después de la lluvia (1987) se configura como poeta-profeta, poeta-Casandra pues preanuncia metafóricamente lo que ha de suceder en pocos años en Berlín: la caída del muro. Y en ese futuro todavía por venir, se ve a sí mismo desfasado, como «último vestigio de una especie extinguida / / paseándome entre los restos / como un fantasma empecinado» («Berlín, $1980 \mathrm{IV} ») .{ }^{85}$ En este volumen -inundado por un léxico fluido, líquido («lluvia», «acuático», «nieve», «nieve derretida», «mar», «flotar», «licuar», «lago») o asociado con él («pez», «nave», «islas») que desdibuja las cosas («Cuando en las ciudades desconocidas llueve / el agua que cae me cuenta las cosas que no sé»; «Berlín, 1980») ${ }^{86}$ o las conecta entre sí («Las analogías vibran / como los objetos diversos / de la galera de un mago»; «Tarde de lluvia») ${ }^{87}$ - , un poeta viajero va recorriendo ciudades europeas, tradiciones ( «Remo, con oscura fuerza, / ensimismada, / en las borrascosas aguas de viejos mitos»; «El naufragio como metáfora (Amsterdam)») ${ }^{88}$ y cuadros. Se ensimisma en una imaginería apocalíptica («y lejano se escucha el retumbar de cosas que se rompen, / cielos que se precipitan, árboles quebrados»; Charlottemburg en invierno» $)^{89}$ mientras añora un pasado - sobre todo el de una «Infancia» en la que los contrarios estaban unidos («Allá en el principio / todas las cosas estaban juntas, / infinitas en el número / y en la pequeñez. / Y mientras todo estaba junto / el dolor era imposible / la pequeñez, invisible»). ${ }^{90}$

Este libro se titula como una obra de Marx Ernst y se relaciona a través de la imaginería acuática con otros cuadros de Ernst y de Turner anticipando lo que se volverá una importante vertiente en la obra de Peri Rossi -la écfrasis-con un punto culminante en Las musas inquietantes $1999,{ }^{91}$ cuyo título a su vez remite a un cuadro de De Chirico. En la descripción del cuadro de Ernst vemos la realidad contemplada

83 Ibid., p. 513.

84 Ibid., p. 449.

85 Ibid., p. 501.

86 Ibid., p. 491.

87 Ibid., p. 482.

88 Ibid., p. 460.

89 Ibid., p. 493.

90 Ibid., p. 443.

91 Las musas... es un volumen ausente de Poesía reunida, quizás por la complicación y el costo que habría acarreado reproducir las imágenes a las que las poesías hacen referencia. 
como un palimpsesto del que emerge otra, oculta porque «Ha llovido magma hirviente / licuando todas las formas» $y$, sin embargo «... quedamente, / por debajo de las formas fosilizadas / y la confusión de gestos, / se sospecha / la vida larvaria / que comienza a latir, / con un espasmo de horror. / Círculo infernal del eterno retorno» («Europa después de la lluvia (Marx Ernst)»). ${ }^{92}$ En «Correspondencias II» uno de los naufragios de Turner inspira una poesía en condicional y por negación: «Y hubiéramos ido a mirar los naufragios de Turner [. . . / si no fuera / . . / que no quiero ver mis sueños reflejados». ${ }^{93}$ La écfrasis se juega, pues, no entre la palabra escrita y los cuadros de Turner sino entre la relación estrecha que existe entre los naufragios pictóricos y los de los sueños del yo poético - algo desarrollado por Peri Rossi en su «Poesía y pintura ${ }^{94}$ - los que evocan un naufragio existencial ya sucedido.

Como hemos visto, en Europa. . . y en Las musas. . ., Peri Rossi pasa de la intertextualidad a la intermedialidad; del mismo modo, en su escritura una cosa puede deslizarse en otra: de la imagen del cuadro a los sueños y de los sueños a una situación existencial, ya pasada; o, en «Las mutantes», las niñas del cuadro del mismo título de Leonor Fini, están a punto de transformarse en gatos, «como si la mutación fuera uno / de los juegos infantiles». ${ }^{95}$

El resultado es la transformación de la cosa y la metamorfosis de su sentido; traslación que ocurre porque el deseo es movimiento y el hablante perirossiano está situado, por lo general, en un borde o frontera:

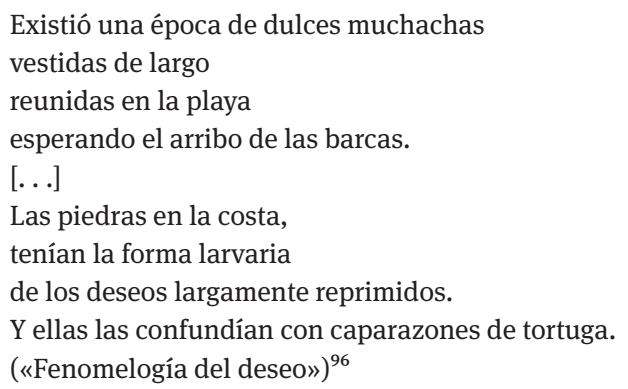

92 Cristina Peri Rossi: Poesía, p. 464-465.

93 Ibid., p. 515.

94 Cristina Peri Rossi: «Poesía y pintura». In: Revista Canadiense de Estudios Hispánicos 28-1 (2003).

95 Cristina Peri Rossi: Las musas inquietantes. Barcelona: Lumen 1999, p. 111.

96 Cristina Peri Rossi: Poesía, p. 514. 
Como se ha visto, un paradigma de la escritura de Cristina Peri Rossi es «Barloventear. Avanzar contra la dirección del viento» ${ }^{97}$ en el que la poesía se recorta entre dos silencios y se funda en la intensidad por su voluntad de hablar «contra»; como cuando se refiere, por ejemplo, a la condición femenina -también desde un punto de vista homoerótico en décadas difíciles - reivindicándola frente a una sociedad patriarcal ( «Soy la advenediza / la perturbadora / la desordenadora de los sexos / la transgresora / [ . . ] / Hablo la lengua de los conquistadores / pero digo lo opuesto de lo que ellos dicen», "Condición de mujer»). ${ }^{98}$

Otro paradigma es singlar - vocablo que señala la dirección precisa hacia donde va una nave- que va indicando el puntual movimiento de su respiro creativo fundado, para sorprender y sorprenderse, en la transformación, en la metamorfosis, en la traslación: una forma de saltar «los sellos / de la memoria antigua» («Poética») ${ }^{99}$ respecto del mundo objetivo pero también respecto de la propia identidad; de allí que no sea raro que Peri Rossi adhiera con vigor a ese «Je est un autre» que refleja no solo su escisión diaspórica, sino que le permite también ir configurando un yo o varios simulacros del mismo para decir y contradecir perspectivas y temas, evitando la fijeza de una sola visión. A la vez, no es raro que busque resolver la escisión del yo a través de un personaje que metalépticamente se desliza de su propia autobiografía - como lo hizo también Rosario Castellanos - para hacerlo entrar en el espacio imaginario (i.e.: «Biografía»; «Enfermedad»; «Contra Flaubert», «Mis contemporáneos»-entre otros de Aquella noche, 1996- o «Punto de encuentro», «Convalescencia», «Para qué sirve la lectura»-entre otros de Playstation, 2009-) por medio del recurso del correlato autorial. ${ }^{100}$

Babel bárbara (1991) universaliza la visión porque intenta hablar de la condición humana, la nuestra, la de los hombres que «[S]omos las palabras de ese Dios / confuso / que en eterna soledad / habla para sí mismo» («Los hijos de Babel»). ${ }^{101}$ En una de sus últimas entrevistas, Peri Rossi dijo que «si tuviera que elegir uno solo de mis poemas, elegiría posiblemente 〈Los hijos de Babel〉 [. . .] el único que me sé de memoria» ${ }^{102}$ y que «reúne las cualidades imprescindibles de la poesía: la mayor cantidad de significados en la menor cantidad de palabras». ${ }^{103}$

97 Ibid., p. 170.

98 Ibid., p. 559.

99 Ibid., p. 620.

100 Laura Scarano: «La cuestión del sujeto en la poesía de Blas de Otero: pluralidad y fragmentación de la voz». In: Anales de la Literatura Española Contemporánea 19, 1-2 (1994), p. 113-131.

101 Cristina Peri Rossi: Poesía, p. 523.

102 Claudia Pérez: «Entrevista», p. 361.

103 Ibid., p. 361. 
En el volumen, de los hombres, «sombra de lo que pudimos ser / en remoto paraíso» («La condena»), ${ }^{104}$ resaltan dos figuras, la de la extranjera y la de un sujeto poético llamado por Babel, «extranjero»y «poeta» («Babel, el despertar»). ${ }^{105}$ Este, asumiendo el papel de ese dios, también él bárbaro, porque «en sueños balbucea» («Los hijos de Babel») ${ }^{106}$-un balbuceo que el título del libro reproduce fonéticamente ${ }^{107}$ - bautiza a la huésped dándole una identidad «contra» todo lo que la evidencia: su desamparo, «su altiva desnudez», «la obstinación de su silencio» («La extranjera»). ${ }^{108}$ Babel se transforma, pues, en el tú del poemario y emite un grito que el yo poético reproduce (¿traduce?) como una fórmula que la identifica con una figura mítica - diría la única - asumida por los sujetos poéticos perirossianos en otros libros, aunque con otra valencia: «Poeta - grita Babel- / soy la ciega de las lenguas / la Casandra en la noche oscura de los significantes» («El bautismo»). ${ }^{109}$

Así pues, las tres figuras que se perfilan en estos sesenta poemas se van deslizando unas dentro en otras: Babel con su lengua bárbara es análoga al dios que balbucea en sueños, y el sujeto poético, también él «confuso», balbucea como Dios «babélicas palabras / de imposible traducción» («Las leyes de la hospitali$\operatorname{dad} »)^{110}$ - como las que pronuncia la extranjera-. Y ante el silencio obstinado de esta, el yo la bautiza con un nombre secreto, «Babel», signo que dice algo que no tiene un significado preciso como lo tienen los signos lingüísticos comunes; por el contrario, la palabra demuestra una estrecha pertenencia a un tiempo originario y su propiedad es la del continuo movimiento, tanto como el del árbol de la cruz, signo del Sacrificio en las Sagradas Escrituras y hoy, de la Reconciliación. ${ }^{111}$ De hecho, si «Babel» hace referencia al caos babélico («-bélal era [. . .] el etimo de la confusión»), asimismo «puede desembocar en una dimensión sacra y benéfica», de hecho, «-bab-êl significaba puerta de Dios». ${ }^{112}$

Como decía, el sujeto poético bautiza al tú «contra» todo lo que la define; por lo tanto, la recrea, la transfigura en otra, en una suerte de simulacro («[. . .] en ti

104 Cristina Peri Rossi: Poesía, p. 524.

105 Ibid., p. 544.

106 Ibid., p. 523.

107 «Bárbaro» proviene de una onomatopeya «bar-bar» que significaba en griego barbotear, balbucear, barbullar, queriendo significar con ello, la incomprensión, la incapacidad del logos (palabra) a los que estaban fuera de la polis» (Jorge Lozano: «Sin límites», p. 186).

108 Cristina Peri Rossi: Poesía, p. 528.

109 Ibid., p. 529.

110 Ibid., p. 533.

111 Michel Foucault: «La prose».

112 Joaquín Manzi: «De cuerpo y letra: la hospitalidad». In: Jesús Gómez-de-Tejada (coord.): Cristina Peri Rossi: Erotismo, p. 107. 
hago la síntesis, / como si fueras mi cobaya»; "Anacronismos»). ${ }^{113}$ Por lo tanto, el yo, mientras pone en evidencia la paradoja de «Las leyes de la hospitalidad», ${ }^{114}$ al mismo tiempo está poniendo en acto una «hospitalidad literaria», algo que se aclara y subraya en otros poemas, como «Identidad» («Te nombro, luego existes»). ${ }^{115}$

Así pues, Babel emerge de la escritura «como un lento animal antiguo / del Mesozoico / con las extremidades fijas / en el lodo prenatal» («Antropología») ${ }^{\mathbf{1 1 6}}$ - un lodo que recuerda el de las ciénagas y lagunas ámbito de Artemisa, quien «tiene su lugar [. . . ] a orillas del mar, en las zonas costeras, donde se confunden los límites de la tierra y el agua. Se trata de los confines, las zonas limítrofes, las fronteras donde se establece contacto con el Otro [... .], donde se codean lo salvaje y lo cultivado: para oponerse pero a la vez para interpenetrarse». ${ }^{117}$

Babel, más cercana a lo primordial que a lo simbólico («[A]nterior a la cultura / a la perversión del instinto / a la transformación del hambre / en apetito / y del sexo / en fantasía»), ${ }^{118}$ tiene una extraña relación con las palabras de una lengua que desconoce, por eso «. . .violenta, / enfurecida, / hojea antiguos diccionarios / como un profanador de tumbas» («El desafío»). ${ }^{119} \mathrm{~A}$ veces revuelve «[... ] las aguas oscuras de las lenguas / como una antigua pescadora / [ . . . / y cuando vuelve a salir del fondo de las aguas / [ . . ] / porta gloriosa una palabra, / una sola / [. . . / amuleto de un dios permanentemente insatisfecho» («La pescadora»). ${ }^{120}$

Lo erótico establece un vínculo entre el yo y Babel de carácter ambiguo, porque si bien el sujeto poético aparece con marcas gramaticales masculinas («extranjero», «sumiso»), la relación con la extranjera presenta connotaciones homoeróticas: porque al enseñarle la propia lengua a Babel, ella pone «ojos asombrados» ante «la palabra incesto», ${ }^{121}$ un vocablo asociado a la temática del amor lesbiano ya en Lingüística General («Hacemos el amor incestuosamente / escandalizando a los peces / y a los buenos ciudadanos de este / y de todos los partidos»; ;22) algo que se subraya en modo siempre más explícito en los libros

113 Cristina Peri Rossi: Poesía, p. 540.

114 Título de uno de los poemas del volumen y el mismo título de la trilogía novelística de Pierre Klossowski, hermano del pintor Balthus cuyo cuadro «La lección de guitarra» inspira una poesía de Las musas inquietantes.

115 Cristina Peri Rossi: Poesía, p. 581.

116 Ibid., p. 564.

117 Jorge Lozano: «Sin límites», p. 184.

118 Cristina Peri Rossi: Poesía, p. 564.

119 Ibid., p. 546.

120 Ibid., p. 547.

121 Ibid., p. 542.

122 Ibid., p. 436. 
posteriores a Babel. . . y, formalmente, se representa con imágenes y metáforas que juegan con las ideas de semejanza, de igualdad y siamesidad.

Una suerte de dislocación temporal («la memoria que traes de lo antiguo, / ebria de heroicidades, / pathos excesivo para el día contemporáneo», «Anacronismos» ${ }^{123}$ ) y de obscenidad caracteriza a Babel; obscenidad no sólo entendida como procacidad, sino como lo que tiene todas las propiedades de la zona oculta y de un lenguaje anterior a las palabras («sus manos son las palabras / de un mudo / que en el terror del silencio / sabe que hay un secreto»; «Babel desnuda»). ${ }^{124}$

\subsection{Poética fronteriza}

El crítico Carlos Raúl Narváez, se ocupó tempranamente de la poética fronteriza de Cristina Peri Rossi enfocándola en Diáspora, Descripción de un naufragio y Lingüística General desde el punto de vista de la intertextualidad. Y, desde esta perspectiva, decía: «Es esta una poética que defiende la noción de que el texto literario es una obra sin fronteras, un orbe ficticio, abierto, producto de un sujeto plural, en cuya constitución interviene la voz poética colectiva conformada por CPR y otros autores cuyas ideologías, preocupaciones estéticas o literarias, la autora comparte». ${ }^{125}$

Mi visión, sin desechar la de Narváez, prefiere enfocar la poética perirossiana desde un punto de vista de las transfiguraciones, las metamorfosis que hacen emerger lo que está debajo del palimpsesto escritural porque

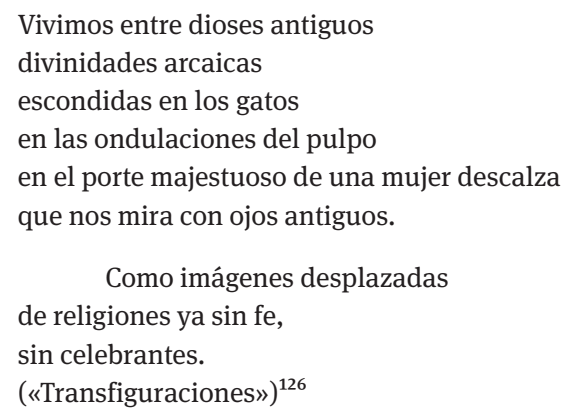

123 Ibid., p. 540.

124 Ibid., p. 579.

125 Carlos Raúl Narváez: «La poética del texto sin fronteras: Descripción de un naufragio, Diáspora, Lingüística general de Cristina Peri Rossi». In: Inti 28 (1988), p. 86.

126 Cristina Peri Rossi: Poesía, p. 526. 
Como ha sido visto en Babel bárbara, la triple transfiguración del yo y la creación de un simulacro para acoger a la extranjera demuestran una «idea de frontera como lugar de paso, de traducción, de ‘apropiación de lo extraño en palabras de Gadamer [. . .] y no de negación»; un espacio que por su continuo intercambio, movimiento y evolución «culmina en la mezcla y en la hibridación». ${ }^{127}$ Y si desde la cultura latina la frontera ha sido un espacio que divide lo sacro de lo profano, ${ }^{128}$ esos dos ámbitos son atravesados con frecuencia en las poesías eróticas de Peri Rossi (i.e. «Misa profana»), ${ }^{129}$ llegando en algunos casos a rozar lo abyecto («Comunión» $\mathrm{y}$ «Comunión II») ${ }^{130}$ entendido este como «lo que perturba una identidad, un sistema, un orden, lo que no respeta límites, reglas, jerarquías, lugares, perspectivas»; "lo que altera, trastorna y establece la mezcla, el desorden, el desconcierto». ${ }^{131}$ De este modo, la poética perirossiana tiende a anular las oposiciones dialécticas para fundarse no solo en la metáfora, sino sobre todo en la metalepsis, entendiendo la misma sea como transgresión de los niveles enunciativos o diegéticos, sea como figura vinculada con la metonimia, pues permite expresar una acción mediante un cambio semántico por el cual una idea se elige con el nombre de otra sirviéndose de alguna relación existente entre las dos.

Así pues, esta poética crea, por una parte, una serie de sujetos que dan cuenta retóricamente de las mutaciones de lo real. Si Peri Rossi rechaza las catalogaciones e insiste en hablar de su escritura como «transgresiva» en el panorama literario contemporáneo, esta transgresión se pone en práctica no sólo por los temas elegidos sino sobre todo por su predilección a deslizar, trasladar, traducir, transfigurar los elementos de la materia verbal unos en otros, transportándolos de un lado a otro de un límite que, poco a poco, se va disolviendo figurativamente, como sucede entre el cielo y el mar en los cuadros de Turner, pintor que la escritora aprecia por su gran intensidad. Todo esto se revierte en una imaginería que diluye los marcos, los márgenes, los límites («La cúpula se licúa en la humedad / como una isla de moho / flotando en el espacio», "Charlottemburg en invierno»; ${ }^{132}$ "En sus ojos acuosos / hubiera navegado toda la vida / si no fuera / que no tienen

127 Teresa Velázquez: «Presentación y bibliografía. Diálogo disciplinar e interacciones teóricas: las fronteras y sus permeabilidades». In: Fronteras. De Signis 13, número especial (2009), p. 14.

128 Raúl Magallón Rosa: «Vagabundos».

129 Cristina Peri Rossi: Poesía.

130 Cristina Peri Rossi: La noche y su artificio. Palencia: Cálamo 2014.

131 María José Bruña Bragado: «Abyecto/sublime: líneas de fuga y pliegues de resistencia en la poesía de Cristina Peri Rossi». In: Jesús Gómez-de-Tejada (coord.): Cristina Peri Rossi: Erotismo, p. 139.

132 Cristina Peri Rossi: Poesía, p. 493. 
orillas». ${ }^{133}$ ) En estas mutaciones se produce un cambio semántico que puede unificar los opuestos para retornar al momento primigenio que precede al lenguaje.

Por otra parte, autor implícito, sujeto poético y personajes atraviesan los límites establecidos entre la enunciación y la enunciación enunciada y, en los diversos libros, van delineando un perfil de la escritura y de la escritora virtual. Personajes que reiteran en poesía lo dicho por la autora en sus ensayos y artículos periodísticos o, en «Las replicantes» (del volumen homónimo, cuyo título juega ambivalentemente con la repetición encarnada en los androides, pero también con el aspecto contestatario del replicar), hacen referencia a la actividad literaria, aunque en una situación y un contexto universales, para acabar constituyendo un simulacro del autor empírico: «La otra noche / después de una lectura de poemas / firmaba ejemplares / de mi último libro». ${ }^{134}$

Además, si los primeros sujetos poéticos de Peri Rossi se configuran como sujetos erotizados (por y con las palabras y por y con las mujeres) y como sujetos políticos y diaspóricos, a medida que pasa el tiempo se definen o son definidos más precisamente como «Poeta» (así llama Babel al yo) absolutizando ese papel: alguien que establece máximas, definiciones y escribe asimismo textos con títulos relacionados con esa identidad, volviéndola dominante; títulos de poesías que se comportan «como «un acto de habla» que espera ciertas reacciones del lector y que le permite al escritor generar efectos de sentido y estéticos específicos». ${ }^{135}$

Sin embargo, algunos matices pueden observarse en esto: en Evohé, Lingüística General y Babel bárbara, para dar dos ejemplos, se entrevé un lenguaje «con visible separación de las construcciones referenciales que la mimetización de acciones históricas parece imponer a los discursos narrativos» ${ }^{136}$ y una superación del contexto del sujeto empírico con el fin de universalizar las palabras, como si el argumento amoroso, la anécdota (biográfica o no) hubiese sido encontrada a partir del poetar mismo, es decir, experimentando «el acontecimiento de lenguaje como amor ${ }^{137}$. En cambio, en el primer poemario escrito en España, Estado de exilio (pero publicado en 2003) o en Playstation o Las replicantes, hay un razonar lo vivido poniendo en palabras toda una serie de contenidos que remiten con mayor insistencia a la vida de la autora; se explicitan el desarraigo, el amor por Montevideo, gustos personales como la visión de ciertos cuadros; jugar

133 Ibid., p. 234.

134 Cristina Peri Rossi: Las replicantes. Palencia: Cálamo 2016, p. 55.

135 Víctor Zonana: Poéticas de autor en la literatura argentina (desde 1950), vol. II. Buenos Aires: Corregidor 2010, p. 423.

136 José María Pozuelos Yvancos: «Pragmática», p. 181.

137 Giorgio Agamben: El lenguaje, p. 112. 
con el «Bookworm Deluxe»; ${ }^{138}$ los «ligues» del presente («House»); ${ }^{139}$ los amores del pasado («La ángela de la guarda»); ${ }^{140}$ la edad; las actividades relacionadas con la profesión de escritora, en gran parte llenos de ironía («La sexualidad de la literatura»; «El amor es cursi II») ${ }^{141}$ e incluso datos clínicos (una pneumonía; problemas cardíacos $\left.{ }^{142}\right) .{ }^{143}$

El que el yo empírico, mediante la estrategia del correlato autorial, parezca estar cruzando la frontera que separa la realidad de la ficción para ocupar con su DNI el lugar del sujeto poético ${ }^{144}$ recalca algo que los textos de «arte poética» tienden a poner en práctica al situarse «en los márgenes de〉 o «sobre〉 los planos empírico y fictivo». ${ }^{145}$ Un modo por el cual un autor -en este caso Cristina Peri Rossi- expone en la escritura el propio proyecto literario.

\section{Bibliografía}

Agamben, Giorgio: El lenguaje y la muerte: Un seminario sobre el lugar de la negatividad. Valencia: Pre-Textos 2008.

Borges, Jorge Luis: La muralla y los libros. In: Obra completa. 1923-1972. Buenos Aires: Emecé 1974.

Bruña Bragado, María José: «Abyecto/sublime: líneas de fuga y pliegues de resistencia en la poesía de Cristina Peri Rossi». In: Jesús de Gómez-de-Tejada (coord.): Cristina Peri Rossi: Erotismo, transgresión y exilio. Las voces de Cristina Peri Rossi, p. 137-152. Sevilla: EUS 2017.

138 Cristina Peri Rossi: Habitación.

139 Cristina Peri Rossi: Las replicantes.

140 Ibid.

141 Ibid.

142 Ibid.

143 Esta afirmación parte, aclaremos, de una premisa fundamental: que si en la comunicación verbal se reconocen seis factores (siguiendo a Jakobson) -el contexto, el emitente, el mensaje, el destinatario, el contacto, el código-, los mismos, en la comunicación literaria se reducen a dos, el mensaje y el destinatario, mientras que el contacto presupone la existencia simultánea de todos los otros elementos aquí tan solo presentes como »representaciones» (Michael Rifaterre: Semiotica della poesia. Bologna: Il Mulino 1983, p. 10. Mi traducción).

144 Laura Scarano: «La cuestión». A propósito de la intención de crear un enunciador desdoblado que se vincula al empírico o bien que emana del hablante poético, consúltese también Dominique Combe: «La referencia desdoblada: el sujeto lírico entre la ficción y la autobiografía». In: Fernando Cabo Aseguinolaza (coord.): Teorías sobre la lírica. Madrid: Arcos/Libros 1999.

145 Arturo Casas: «Metapoesía y (pos)crítica: punto de fuga». In: Metaliteratura y metaficción. Balance crítico y perspectivas comparadas, coord. Antonio Gil González. Anthropos 208 (2005), p. 75 . 
Casas, Arturo: «La función autopoética y el problema de la productividad histórica». In: Romera Castilla y Gutiérrez Carbajo (eds.): Poesía histórica y autobiográfica, p. 209-218. Madrid: Visor 2000.

-: «Metapoesía y (pos)crítica: punto de fuga». In: Metaliteratura y metaficción. Balance crítico y perspectivas comparadas, coord. Antonio Gil González. Anthropos 208 (2005), p. 71-81.

-: «Pragmática y poesía». In: Darío Villanueva (compil.): Avances en Teoría de la Literatura (Estética de la Recepción, Pragmática, Teoría Empírica y Teoría de los Polisistemas), p. 229-308. Santiago de Compostela: Universidad de Santiago de Compostela 2012. [1994]. Reedición en poesiagalega.org. Arquivo de poéticas contemporáneas na cultura. http://www.poesiagalega.org/arquivo/ficha/f/1686 [Consultado el 12 de octubre 2020].

Castellanos, Rosario: Poesía no eres tú. Obra poética 1948-1971. México: FCE 2004.

Cayuela González, Carolina: «Metapoesía y pragmática en «El poeta〉 de Vicente Aleixandre». In: Espéculo. Revista de Estudios literarios 34 (2006-2007), s. p. https://webs.ucm.es/ info/especulo/numero34/metaalei.html [Consultado el 12 de octubre 2020].

Combe, Dominique: «La referencia desdoblada: el sujeto lírico entre la ficción y la autobiografía». In: Fernando Cabo Aseguinolaza (coord.): Teorías sobre la lírica, p. 127-153. Madrid: Arco/Libros 1999.

Fariña Busto, María Jesús: «Donde habita el deseo: Eros y el lenguaje poético». In: Jesús Gómez-de-Tejada (coord.): Cristina Peri Rossi: Erotismo, transgresión y exilio. Las voces de Cristina Peri Rossi, p. 69-87. Sevilla: EUS 2017.

Foucault, Michel: «La prose d’Actéon». In: Dits et écrits 1954-1988, tomo I 1954-1969, ed. D. Defert y F. Ewald, p. 326-337. Paris: Gallimard 1964.

García Berrio, Antonio: «Lingüística, literaridad/poeticidad (gramática, pragmática, texto)». In: 1616. Anuario de la Sociedad Española de Literatura General y Comparada 2 (1979), p. $125-168$.

Genette, Gerard: Métalepse. De la figure a la fiction. Paris: Seuil 2004.

Gilmour, Nicola: «Una entrevista con Cristina Peri Rossi». In: Journal of Iberian and Latin American Studies 6-1 (2000), p. 117-135.

Guillén, Claudio: «El sol de los desterrados: Literatura y exilio». In: Múltiples moradas: Ensayo de literatura comparada, p. 29-97. Barcelona: Tusquets 1998.

-: «La expresión total: literatura y obscenidad». In: Múltiples moradas. Ensayo de literatura comparada, p. 234-296. Barcelona: Tusquets 1998.

Hegel, Georg F.: Estetica, vol. 1. Torino: Einaudi 1997.

Lozano, Jorge: «Sin límites: Fronteras y confines en la semiótica de la cultura». In: Fronteras. De Signis 13 (2009), p. 183-190.

Magallón Rosa, Raúl: «Vagabundos de identidad». In: Fronteras. De Signis 13 (2009), p. 152-159.

Magliano, Claudia: «La poesía persigue lo efímero». In: Jesús Gómez-de-Tejada (coord.): Cristina Peri Rossi: Erotismo, transgresión y exilio. Las voces de Cristina Peri Rossi, p. 355-359. Sevilla: EUS 2017.

Manzi, Joaquín: «De cuerpo y letra: la hospitalidad». In: Jesús Gómez-de-Tejada (coord.): Cristina Peri Rossi: Erotismo, transgresión y exilio. Las voces de Cristina Peri Rossi, p. 103-111. Sevilla: EUS 2017.

Narváez, Carlos Raúl: «La poética del texto sin fronteras: Descripción de un naufragio, Diáspora, Lingüística general de Cristina Peri Rossi». In: Inti 28 (1988), p. 75-88.

Ortega, Julio: «Post-teoría y estudios transatlánticos». In: Iberoamericana 9 (2003), p. 109-117. Paz, Octavio: El arco y la lira. Editor digital El Cavernas 1967 [1956]. Digital. 
-: Los hijos del limo. Barcelona: Seix Barral 1990.

Pérez, Claudia: «Entrevista a Cristina Peri Rossi». In: Jesús Gómez-de-Tejada (coord.): Cristina

Peri Rossi: Erotismo, transgresión y exilio. Las voces de Cristina Peri Rossi, p. 361-371.

Sevilla: EUS 2017.

Pérez Firmat, Gustavo: Cincuenta lecciones de exilio y desexilio. Miami: Universal 2000.

Pérez Fondevila, Aína: «Del deseo y sus accesos: una entrevista a Cristina Peri Rossi».

In: Lectora 11 (2005), p. 181-193.

Peri Rossi, Cristina: Fantasías eróticas. Barcelona: Ediciones Temas de Hoy 1991.

-: «Escribir como transgresión». In: Lectora: revista de dones i textualitat 1 (1995), p. 3-6.

-: Las musas inquietantes. Barcelona: Lumen 1999.

-: «Poesía y pintura». In: Revista Canadiense de Estudios Hispánicos 28-1 (2003), p. 11-14.

-: Poesía reunida. Barcelona: Lumen 2005.

-: Habitación de hotel. Barcelona: Plaza y Janés 2007.

-: «Lectura comentada». In: R. Mérida Jiménez (ed.): Diàlegs, gais, lesbians, queers, p. 15-38.

Lleida: Universitat de Lleida 2007.

-: Playstation. Madrid: Visor 2009.

-: La noche y su artificio. Palencia: Cálamo 2014.

-: Las replicantes. Palencia: Cálamo 2016.

-: «Detente, instante eres tan bello». In: Jesús Gómez-de-Tejada (coord.): Cristina Peri Rossi:

Erotismo, transgresión y exilio. Las voces de Cristina Peri Rossi, p. 21-34. Sevilla: EUS 2017.

Pozuelo Yvancos, José María: «Pragmática, poesía y metapoesía en «El Poeta〉 de Vicente Aleixandre». In: Fernando Cabo (compil.): Teorías sobre la lírica, p. 177-201. Madrid: Arco Libros 1999.

Rifaterre, Michael: Semiotica della poesia. Bologna: Il Mulino 1983.

Rodríguez Gutiérrez, Milena: «Poetas transatlánticas: hispanoamericanas en la España de hoy. Cristina Peri Rossi, Ana Becciu, Isel Rivero». In: Anales de literatura hispanoamericana 38 (2009), p. 111-133.

Salomone, Alicia: «Analogía, ironía y escritura femenina: Repensando a Octavio Paz desde la teoría crítica feminista». In: Taller de Letras 38 (2006), p. 75-94.

San Román, Gustavo: «Entrevista a Cristina Peri Rossi». In: Revista Iberoamericana LVIII, 160-161 (1992), p. 1042-1048.

Scarano, Laura. «Escribo que escribo: de la metapoesía a las autopoéticas». In: Tropelías. Revista de Teoría de la Literatura y Literatura Comparada 2 (2017), p. 133-152.

-: «La cuestión del sujeto en la poesía de Blas de Otero: pluralidad y fragmentación de la voz». In: Anales de la Literatura Española Contemporánea 19, 1-2 (1994), p. 113-131.

Velázquez, Teresa: «Presentación y bibliografía. Diálogo disciplinar e interacciones teóricas: las fronteras y sus permeabilidades». In: Fronteras. De Signis 13, número especial (2009), p. 9-17.

Verani, Hugo: «Muestras de la poesía uruguaya actual». In: Hispamérica 16 (1977), p. 61-95.

-: «La rebelión del cuerpo y el lenguaje (A propósito de Cristina Peri Rossi)». In: Revista de la Universidad de México 37, 11 (1982), p. 19-22.

Zonana, Víctor: Poéticas de autor en la literatura argentina (desde 1950), vol. II. Buenos Aires: Corregidor 2010. 